\title{
SLC39A4 Gene
}

National Cancer Institute

\section{Source}

National Cancer Institute. SLC39A4 Gene. NCI Thesaurus. Code C139920.

This gene is involved in zinc homeostasis. 